\title{
Studies on articular and general toxicity of orally administered ozenoxacin in juvenile rats and dogs
}

\author{
Jorge Ignacio González Borroto ${ }^{1}$, Malaika Sharon Awori², Luc Chouinard², Susan Y Smith², \\ Cristina Tarragó ${ }^{3}$, Teresa Blazquez ${ }^{1}$ Domingo Gargallo-Viola ${ }^{1}$ \& Ilonka Zsolt*,1 \\ ${ }^{1}$ Medical Department, Ferrer Internacional SA, Barcelona, Spain \\ ${ }^{2}$ Charles River Laboratories Montreal ULC., Senneville, Canada \\ ${ }^{3}$ Spherium Biomed, Barcelona, Spain \\ *Author for correspondence: izsolt@ferrer.com
}

\begin{abstract}
Aim: Ozenoxacin is a nonfluorinated quinolone antibacterial approved for topical treatment of impetigo. Because quinolones have known chondrotoxic effects in juvenile animals, the potential toxicity of ozenoxacin was assessed in preclinical studies. Materials \& methods: Ozenoxacin or ofloxacin (300 mg/kg/day for 5 days, for each compound) was orally administered to juvenile rats, and oral ozenoxacin (10-100 mg/kg/day for 14 days) was administered to juvenile dogs. Results: In juvenile rats, ozenoxacin showed no chondrotoxicity, whereas ofloxacin produced typical quinolone-induced lesions in articular cartilage in three of ten rats. Oral ozenoxacin administration to juvenile dogs showed no chondrotoxicity or toxicologically relevant findings in selected target organs. Conclusion: Ozenoxacin was generally well-tolerated in juvenile rats and dogs, with no evidence of quinolone-induced arthropathy.
\end{abstract}

First draft submitted: 4 December 2017; Accepted for publication: 16 March 2018; Published online: 10 May 2018

Keywords: articular toxicity $\bullet$ dogs $\bullet$ ozenoxacin $\bullet$ quinolones $\bullet$ rats

Quinolones are one of the largest classes of antibacterial agents used worldwide. New compounds continue to be developed since these agents were first applied in a clinical setting more than 40 years ago [1]. Ozenoxacin is a nonfluorinated quinolone antibacterial $[2,3]$ that was shown in two recent Phase III trials to be effective and safe in the treatment of impetigo in adults and children ( 2 months and older) as a $1 \%$ cream formulation for topical application $[4,5]$.

Preclinical evaluation of quinolones, notably second-generation fluoroquinolones, showed that chondrotoxicity was an adverse effect [6-8]. Chondrotoxicity was observed in juvenile dogs following treatment with ciprofloxacin, norfloxacin [9] and ofloxacin [10]; and in juvenile rats after treatment with sparfloxacin [8], ofloxacin [11,12] and ciprofloxacin [13].

Accurate assessment of adverse events is an important step during the preclinical development of compounds. Here, we examined the potential articular toxicity of ozenoxacin in preclinical studies in juvenile rats and juvenile dogs after repeated oral administration. The potential toxicological effects of ozenoxacin on other organ systems were also examined. Experiments in juvenile rats compared the potential chondrotoxicity of ozenoxacin with ofloxacin, which has known chondrotoxic effects in this model [10,11], and placebo. Experiments in juvenile dogs compared ozenoxacin with vehicle control treated animals, and measured toxicokinetic parameters to investigate systemic exposure.

\section{Materials \& methods}

Toxicity study in juvenile rats

A total of 36 male juvenile Sprague-Dawley rats, 3 weeks old, weighing $90 \mathrm{~g} \pm 20 \%$ (Charles River Laboratories,

Senneville, Canada) were used in the study. 
Animals were housed individually in $500 \mathrm{~cm}^{2}$ surface Macrolon ${ }^{\circledR}$ cages, and received rat-mouse food (Harlan, Bicester, Oxfordshire, UK) and water ad libitum. The temperature range was $20.5-22.5^{\circ} \mathrm{C}$, with humidity of 40-70\% and a light cycle of $12 \mathrm{~h}$ light (maximum $320 \mathrm{lux}$ ) and $12 \mathrm{~h}$ darkness.

Rats were assigned to three groups comprising a control $(\mathrm{n}=10)$, ofloxacin-treated $(\mathrm{n}=10)$ and ozenoxacintreated $(\mathrm{n}=16)$ group. Animals were treated once-daily, by oral gavage, for 5 days with $300 \mathrm{mg} / \mathrm{kg} / \mathrm{day}$ of ozenoxacin or $300 \mathrm{mg} / \mathrm{kg} /$ day of ofloxacin. Control animals received vehicle $(0.25 \%$ of agar in bi-distilled water) alone. Following treatment, animals had a recovery period of 2 days prior to sacrifice.

Body weight and clinical signs were monitored periodically during the study. At the end of the recovery period (7 days from study start) rats were sacrificed by $\mathrm{CO}_{2}$ inhalation, which was followed by a full necropsy consisting of external and internal examination.

Aspartate aminotransferase (AST) and alanine aminotransferase (ALT) were measured using a selective chemistry analyzer on serum samples prepared from blood taken from the external jugular vein of dead animals immediately postsacrifice.

Histological examination was performed on the liver, kidneys and tendon and cartilage from the tibia-femur joint from each animal. Specimens were fixed in a neutralized 10\% aqueous solution of formaldehyde, and embedded in paraffin. Sections, 5- $\mu \mathrm{m}$ thick, were stained with hematoxylin-eosin (H\&E).

\section{Statistical analysis}

Levene's test was used to test for homogeneity of variance and Kolmogorov-Smirnov's test was used to test for distribution normality. Means in each group were compared using analysis of variance (ANOVA). Pairwise post hoc comparisons of treatment versus control groups were performed using the unilateral Dunnet's test. A significance level of $\mathrm{p}<0.05$ was used in all tests.

\section{Toxicity study in juvenile dogs}

Juvenile beagle dogs were obtained from Covance Research Products (VA, USA), with males and females having weight ranges of 3.8-5.9 kg and 3.1-4.7 kg, respectively. Dogs were housed socially in stainless steel cages, with a vinyl coated mesh floor and an automatic watering valve. Up to three animals of the same sex and dosing group were housed together.

Temperature ranged from 17 to $23^{\circ} \mathrm{C}$ (mean of $19.8^{\circ} \mathrm{C}$ during the study), with humidity of $30-70 \%$ (mean $50.8 \%$ ). The light cycle was $12 \mathrm{~h}$ light and $12 \mathrm{~h}$ dark, except during designated procedures. Dogs received certified feed (Eukanuba Premium Performance Formula) ad libitum, except during designated procedures. No food was given at least $1 \mathrm{~h}$ before treatment, and at least $2 \mathrm{~h}$ afterward.

Dogs were aged 12 weeks at the start of treatment and were randomized to treatment and recovery groups using body weight as a stratification factor. Ozenoxacin was administered by daily oral gavage at 10, 25, 50 or $100 \mathrm{mg} / \mathrm{kg} /$ day for 14 days. Control animals received vehicle only. A dose volume of $10 \mathrm{ml} / \mathrm{kg}$ per animal was used. Each treatment group comprised four male and four female dogs, and a further two male and two female dogs were assessed in a recovery period which lasted 2 weeks (days 15-28), following 14 days of treatment.

Ophthalmological examinations and electrocardiographic (ECG) recordings were performed prior to treatment, during the second week of the treatment period, and at the end of the recovery period. All examinations during the treatment phase were performed predosing. Indirect ophthalmology was performed by funduscopy and biomicroscopic examinations using a slit lamp, with 1\% mydriacyl used for pupil dilation.

ECG recordings during the treatment period were taken at the estimated $T_{\max }$ (from approximately $1 \mathrm{~h}$ after dosing, up to $1 \mathrm{~h} 12 \mathrm{~min}$ post dosing on day 13). ECG recordings were performed on day 13 using limb leads I, II, III, aVR, aVL and aVF at a standard recording speed of $50 \mathrm{~mm} / \mathrm{s}$ and an initial standard sensitivity of 10 or $20 \mathrm{~mm} / \mathrm{mV}$.

Blood samples were obtained from the femoral vein, with animals having been deprived of food approximately $7 \mathrm{~h}$ prior to collection. Urine was collected over an approximate $7 \mathrm{~h}$ period during food deprivation, with water available ad libitum.

\section{Hematology}

Hematological parameters assessed were red blood cell (RBC) morphology, RBC count, RBC indices (mean cell volume, mean cell hemoglobin, mean cell hemoglobin concentration and red cell distribution width), hematocrit, hemoglobin concentration, platelet count, mean platelet volume, reticulocyte count and total and differential white 
blood cell (WBC) counts. Complete blood count was evaluated on the Advia 120 Hematology System (Siemens, USA).

Coagulation parameters assessed were activated partial thromboplastin time and prothrombin time. Coagulation time was evaluated on the ACL Advance Coagulation Analyzer (Instrumentation Laboratory, USA).

\section{Clinical biochemistry}

Serum concentrations of multiple parameters were measured, including ALT, AST, alkaline phosphatase (ALP), total bilirubin, direct bilirubin, indirect bilirubin, urea nitrogen, creatinine, glucose, cholesterol, triglycerides, total serum protein, albumin, globulin, albumin/globulin (A/G) ratio and electrolytes. Biochemistry was performed on the Hitachi P800 Automated Chemistry Analyzer (Roche, USA).

\section{Urinalysis}

Parameters assessed were bilirubin, blood, glucose, ketones, nitrite, $\mathrm{pH}$, protein, urobilinogen, volume, color and appearance, specific gravity and microscopy of centrifuged deposit. Urinalysis was performed on the Clinitek Atlas Automated Urine Chemistry Analyzer (Siemens).

\section{Toxicokinetics}

Heparinized blood samples were collected from all ozenoxacin-treated animals on days 1 and 14 at predosing, and at 1, 3, 6, 12 and 24 h postdosing; and on days 3, 6, 9 and 12 at predosing only. For animals in the control group, blood was collected at predosing and at $3 \mathrm{~h}$ postdosing on days 1 and 14 . Ozenoxacin plasma concentrations were analyzed using validated LC-MS/MS.

Noncompartmental toxicokinetic analysis was performed on plasma concentration data using WinNonlin version 5.2.1 software (Pharsight Corp., CA, USA). The area under the curve (AUC) versus time data was calculated using the linear trapezoidal method. Whenever possible, the terminal elimination phase of the toxicokinetic profile was identified and its slope calculated using loglinear regression. Toxicokinetic parameters describing the systemic exposure of ozenoxacin were estimated from plasma concentration values, the dosing regimen, the AUC and the terminal elimination phase rate constant for each animal.

\section{Gross pathology}

At the end of the treatment or recovery periods, animals were euthanized by an overdose of intravenously administered sodium pentobarbital. A full necropsy was performed according to standard operating procedures and consisted of external and internal examinations and a detailed evaluation of articular surfaces of the scapulahumeral, humero-radial, radio-carpal, coxo-femoral, femoro-tibial and tibio-tarsal joints. Sampled tissues were fixed in $10 \%$ neutral buffered formalin.

\section{Histopathology}

Evaluation of the bone/articular surfaces was performed on the proximal (head) and distal regions of the femur, humerus and tibia. Two bilateral sections of each bone were decalcified in formic acid, embedded in paraffin wax, sectioned at a thickness of $5 \mu \mathrm{m}$ and stained with H\&E or Safranin-O.

Additionally, the brain, thymus, lung, liver and kidney were processed for embedding in paraffin wax, and $5-\mu \mathrm{m}$ sections were stained with $\mathrm{H} \& \mathrm{E}$ and evaluated histopathologically.

\section{Bone mineral density}

Bone mineral density measurements were performed using quantitative computed tomography with a XCT research SA bone scanner equipped with version 5.50D software. The distal metaphysis and diaphysis sites were scanned.

\section{Statistical analysis}

Homoscedasticity was tested using Levene's test at the $\mathrm{p}=0.05$ level. A parametric analysis of variance was used for homoscedastic data and, if statistically significant $(\mathrm{p} \leq 0.05)$, Dunnet's test was used for pairwise comparisons of treatment versus control groups. Heteroscedastic data were analyzed using the nonparametric Kruskal-Wallis test and, if significant $(\mathrm{p} \leq 0.05)$, Dunn's test was used to compare treatment versus control groups. Pairwise group comparisons using Dunnet's test or Dunn's test were two-tailed, with significance levels of $\mathrm{p}<0.05, \mathrm{p}<0.01$, or $\mathrm{p}<0.001$ reported. 
Table 1. WBC and WBC differential counts in control and ozenoxacin-treated female dogs ( $\mathrm{n}=6 / \mathrm{group})$ at the end of the treatment period (day 14).

\begin{tabular}{|c|c|c|c|c|c|c|c|}
\hline \multirow{2}{*}{$\begin{array}{l}\text { Ozenoxacin dose } \\
(\mathrm{mg} / \mathrm{kg} / \mathrm{day})\end{array}$} & \multirow[t]{2}{*}{ WBC $\left(10^{6} / \mathrm{ml}\right)$} & \multicolumn{6}{|c|}{ WBC differential counts $\left(10^{6} / \mathrm{ml}\right)$} \\
\hline & & Neutrophils & Lymphocytes & Monocytes & Eosinophils & Basophils & Large unstained cells \\
\hline 0 (control) & $14.068 \pm 2.808$ & $7.408 \pm 1.238$ & $5.257 \pm 1.802$ & $0.848 \pm 0.309$ & $0.432 \pm 0.169$ & $0.053 \pm 0.020$ & $0.073 \pm 0.016$ \\
\hline 10 & $10.913 \pm 1.725^{*}$ & $5.185 \pm 0.842^{\star *}$ & $4.805 \pm 1.074$ & $0.443 \pm 0.204^{\star *}$ & $0.307 \pm 0.204$ & $0.043 \pm 0.020$ & $0.068 \pm 0.029$ \\
\hline 25 & $8.922 \pm 1.680^{\star \star \star}$ & $4.598 \pm 0.852^{\star \star \star}$ & $3.580 \pm 0.930$ & $0.408 \pm 0.103^{\star \star}$ & $0.262 \pm 0.160$ & $0.022 \pm 0.010^{\star *}$ & $0.048 \pm 0.017$ \\
\hline 50 & $8.970 \pm 2.318^{\star \star}$ & $4.593 \pm 1.499^{\star \star \star}$ & $3.707 \pm 0.847$ & $0.387 \pm 0.116^{\star \star}$ & $0.197 \pm 0.069^{*}$ & $0.028 \pm 0.013$ & $0.033 \pm 0.008$ \\
\hline 100 & $9.588 \pm 1.701^{\star *}$ & $4.385 \pm 1.164^{* * *}$ & $4.498 \pm 0.580$ & $0.392 \pm 0.136^{\star *}$ & $0.222 \pm 0.100^{*}$ & $0.033 \pm 0.008$ & $0.058 \pm 0.015$ \\
\hline \multicolumn{8}{|c|}{$\begin{array}{l}\text { Mean } \pm \text { standard deviation data are shown. } \\
{ }^{\star} p<0.05 . \\
{ }^{*} p<0.01 \\
{ }^{\star \star *} p<0.001 \\
\text { WBC: White blood cell. }\end{array}$} \\
\hline
\end{tabular}

\section{Results}

Toxicity study in juvenile rats

There was no mortality and no clinical signs were observed during the toxicity study in juvenile rats. No significant differences in body weight were found between rats treated with ozenoxacin or ofloxacin or in the control group. No treatment-related macroscopic findings were observed in any animal at necropsy.

Serum AST concentrations were significantly increased $(\mathrm{p}<0.05)$ in both treatment groups, whereas no significant changes were observed in ALT levels. In all animals, histopathological changes observed in the liver and kidney were consistent with background lesions in rats of this age.

In juvenile rats treated with ozenoxacin, no histopathological toxicologically relevant changes were found in the synovial membrane $(n=16)$, articular surface $(n=16)$, semilunar cartilage $(n=11)$, rotula $(n=3)$, or tendon $(\mathrm{n}=15)$. Rats in the control group showed no evidence of chrondrotoxicity.

Three rats from the ofloxacin group showed articular cartilage lesions with chondromucinous degeneration (grade 1, $\mathrm{n}=1$; grade 2, $\mathrm{n}=2$ ). Hyperplasia of cartilage forming irregular cartilaginous tissue (grade 2) was noted in two rats and was associated with inflammatory cell infiltration of the synovial membrane (grade 1) in one animal. Granulocytes were noted in the joint cavity (grade 2) in one ofloxacin-treated rat. Rats in the control group showed no evidence of chondrotoxicity.

\section{Toxicity study in juvenile dogs} Clinical observations

No mortality or treatment-related effects of ozenoxacin on ophthalmological and ECG evaluations or urinalysis were identified in the study.

Treatment-related effects of ozenoxacin included decreased activity and tremors in male dogs at $100 \mathrm{mg} / \mathrm{kg} / \mathrm{day}$, and in female dogs at 50 and $100 \mathrm{mg} / \mathrm{kg} /$ day. Clinical signs consistent with emesis (undigested food and white/clear material in cage) were noted in both sexes at ozenoxacin doses of 50 and $100 \mathrm{mg} / \mathrm{kg} / \mathrm{day}$. Salivation and associated wet fur was observed in male dogs at $100 \mathrm{mg} / \mathrm{kg} /$ day and in female dogs at 50 and $100 \mathrm{mg} / \mathrm{kg} /$ day. These clinical signs were not observed during the recovery period.

Ozenoxacin had no consistent or meaningful effects on food consumption. No toxicologically relevant treatmentrelated effects on body weight were noted; differences observed between treatment and control groups were not statistically significant.

\section{Hematology}

A non-dose-dependent decrease in total and differential WBC counts compared with controls was found in male and female dogs at ozenoxacin doses $\geq 10 \mathrm{mg} / \mathrm{kg} /$ day. Statistically significant changes in females were found for WBC, neutrophil and monocyte counts at all doses of ozenoxacin, compared with control levels (Table 1). WBC counts in treatment groups remained relatively low at the end of the recovery period ( $\mathrm{n}=2$; data not shown).

At the end of the treatment period, hematocrit values were significantly reduced in female dogs $(\mathrm{n}=6 /$ group $)$ at 25 $(34.52 \% \pm 1.28 ; \mathrm{p}<0.001), 50(35.60 \% \pm 1.85 ; \mathrm{p}<0.05)$ and $100(35.38 \% \pm 0.83 ; \mathrm{p}<0.01) \mathrm{mg} / \mathrm{kg} / \mathrm{day} \mathrm{doses}$ of ozenoxacin compared with controls $(38.70 \% \pm 2.35)$. However, hemoglobin concentrations were significantly 
Table 2. Ozenoxacin estimated safety margins in pediatric age categories from human equivalent dose based on the NOAEL from juvenile dogs.

\begin{tabular}{|c|c|c|}
\hline Pediatric category and age range & $\begin{array}{l}\text { Mean body weight/proposed therapeutic dose } \\
\mathrm{mg} / \mathrm{kg}^{\dagger} \text { (combined boys-girls) }\end{array}$ & $\begin{array}{l}\text { Safety margin (number of times HED }[\mathrm{mg} / \mathrm{kg}] \text { is over } \\
\text { the proposed therapeutic dose } \mathrm{mg} / \mathrm{kg})^{\dagger}\end{array}$ \\
\hline Infant: 2 months- 2 years & $7.5 \mathrm{~kg} / 1.33 \mathrm{mg} / \mathrm{kg}$ & 41-times the proposed therapeutic dose \\
\hline Young child: $2-6$ years & $17 \mathrm{~kg} / 0.59 \mathrm{mg} / \mathrm{kg}$ & 93-times the proposed therapeutic dose \\
\hline Child: $6-12$ years & $32 \mathrm{~kg} / 0.31 \mathrm{mg} / \mathrm{kg}$ & 177-times the proposed therapeutic dose \\
\hline Adolescent: $12-18$ years & $60 \mathrm{~kg} / 0.17 \mathrm{mg} / \mathrm{kg}$ & 323-times the proposed therapeutic dose \\
\hline
\end{tabular}

${ }^{\dagger}$ Considering approved indication: topical application of a thin layer of ozenoxacin $1 \%$ twice daily (maximum $0.5 \mathrm{~g}$ ) for 5 days.

HED: Human equivalent dose; NOAEL: No observed adverse effect level.

reduced $(\mathrm{p}<0.05)$ only in female dogs at the $25 \mathrm{mg} / \mathrm{kg} /$ day dose of ozenoxacin $(11.53 \mathrm{~g} / \mathrm{dl} \pm 0.47)$ compared with controls $(12.83 \mathrm{~g} / \mathrm{dl} \pm 1.04)$.

At the end of the recovery period, there were no appreciable differences in hematocrit and hemoglobin levels in female $\operatorname{dogs}(\mathrm{n}=2$ /group). Hematocrit values per group were: $37.45 \% \pm 2.33$ in controls; and $36.85 \% \pm 0.21$ at $10 \mathrm{mg} / \mathrm{kg} /$ day; $35.10 \% \pm 1.41$ at $25 \mathrm{mg} / \mathrm{kg} /$ day; $36.10 \% \pm 0.85$ at $50 \mathrm{mg} / \mathrm{kg} /$ day; and $35.40 \% \pm 1.84$ at $100 \mathrm{mg} / \mathrm{kg} /$ day doses of ozenoxacin. At the end of the recovery period, hemoglobin concentrations were $12.05 \mathrm{~g} / \mathrm{dl} \pm 0.21$ in female dogs treated with ozenoxacin $25 \mathrm{mg} / \mathrm{kg} /$ day, and $12.85 \mathrm{~g} / \mathrm{dl} \pm 1.20$ in controls.

\section{Clinical biochemistry}

Compared with controls, non-dose-dependent significant increases in albumin and decreases in globulin concentrations, with associated increases in A/G ratios, were found in both sexes at ozenoxacin doses $\geq 10 \mathrm{mg} / \mathrm{kg} / \mathrm{day}$ at the end of the treatment period. Changes in $A / G$ ratios at doses $\geq 25 \mathrm{mg} / \mathrm{kg} /$ day in female $\operatorname{dogs}(\mathrm{n}=2)$ and at doses $\geq 50 \mathrm{mg} / \mathrm{kg} /$ day in male $\operatorname{dogs}(\mathrm{n}=2)$ persisted at the end of the recovery period (data not shown).

Increases in mean ALP concentrations were found in females at ozenoxacin doses $\geq 25 \mathrm{mg} / \mathrm{kg} /$ day at the end of the treatment period (day 14), although the only statistically significant $(\mathrm{p}<0.05)$ result compared with control was with the $100 \mathrm{mg} / \mathrm{kg} / \mathrm{day}$ dose. Control ALP was $121.0 \pm 25.4 \mathrm{U} / \mathrm{l}$. Mean ALP concentrations in ozenoxacintreated groups were: $151.0 \pm 27.9 \mathrm{U} / \mathrm{l}$ at $25 \mathrm{mg} / \mathrm{kg} /$ day; $142.8 \pm 17.4 \mathrm{U} / \mathrm{l}$ at $50 \mathrm{mg} / \mathrm{kg} / \mathrm{day}$; and $158.0 \pm 10.8 \mathrm{U} / \mathrm{l}$ at $100 \mathrm{mg} / \mathrm{kg} /$ day $(\mathrm{p}<0.05)$. ALP concentrations were also increased in ozenoxacin-treated groups at the end of the recovery period (day 28). Mean values were $149.0 \pm 17.0 \mathrm{U} / \mathrm{l}$ at $25 \mathrm{mg} / \mathrm{kg} / \mathrm{day}, 116.0 \pm 24.0 \mathrm{U} / \mathrm{l}$ at $50 \mathrm{mg} / \mathrm{kg} /$ day and $142.0 \pm 15.6 \mathrm{U} / \mathrm{l}$ at $100 \mathrm{mg} / \mathrm{kg} /$ day, compared with mean ALP of $97.0 \pm 9.9 \mathrm{U} / \mathrm{l}$ in the control group.

Other changes in biochemical parameters were of negligible amplitude and were not considered to be treatmentrelated.

\section{Toxicokinetic profile of ozenoxacin}

Marked interindividual variability within each treatment group led to variability in toxicokinetic parameters. Figure 1 shows mean $\mathrm{C}_{\max }$, mean $\mathrm{AUC}_{(0-\mathrm{t})}$ and mean $\mathrm{t}_{1 / 2}$ in each of the treatment groups. Maximal concentrations of ozenoxacin were generally observed $1 \mathrm{~h}$ post oral gavage administration. However, with increasing doses, a greater proportion of animals exhibited $\mathrm{T}_{\max }$ values at later times (at 3 or $6 \mathrm{~h}$ ).

For the 10 and $25 \mathrm{mg} / \mathrm{kg} /$ day doses of ozenoxacin, mean AUC $(0-t)$ values were generally similar between male and female dogs, but exposure was greater in females at 50 and $100 \mathrm{mg} / \mathrm{kg} /$ day doses. Between day 1 and day 14 , there was a general small decrease in exposure at the 10 and $25 \mathrm{mg} / \mathrm{kg} /$ day doses whereas, at the two highest doses, there was a 3.15-fold increase in exposure suggesting accumulation of ozenoxacin following daily administration. On day 1 , the increase in exposure was generally less than the proportional increase in dosage from 10 to $100 \mathrm{mg} / \mathrm{kg} /$ day; this was seen more clearly in males. On day 14 , the increase in exposure was generally more than the proportional increase in dosage from 10 to $100 \mathrm{mg} / \mathrm{kg} /$ day. Overall, both $\mathrm{C}_{\max }$ and mean AUC (0-t) values on Days 1 and 14 showed that plasma exposure was proportional to dose.

At the no observed adverse effect level (NOAEL) of ozenoxacin, which was $100 \mathrm{mg} / \mathrm{kg} / \mathrm{day}$, mean $\mathrm{C}_{\max }$ and AUC $_{(0-\mathrm{t})}$ values were $10,796 \mathrm{ng} / \mathrm{ml}$ and $63,458 \mathrm{ng} \bullet / \mathrm{ml}$, respectively (combined data from male and female dogs). Based on the human equivalent dose (HED) $(55 \mathrm{mg} / \mathrm{kg}$ ) derived from the NOAEL in juvenile dogs, ozenoxacin has a high safety margin for the approved indication in children (aged 2 months-18 years; Table 2), and also in adults, according to the proposed clinical dose of topically applied ozenoxacin $1 \%$ cream twice daily. 

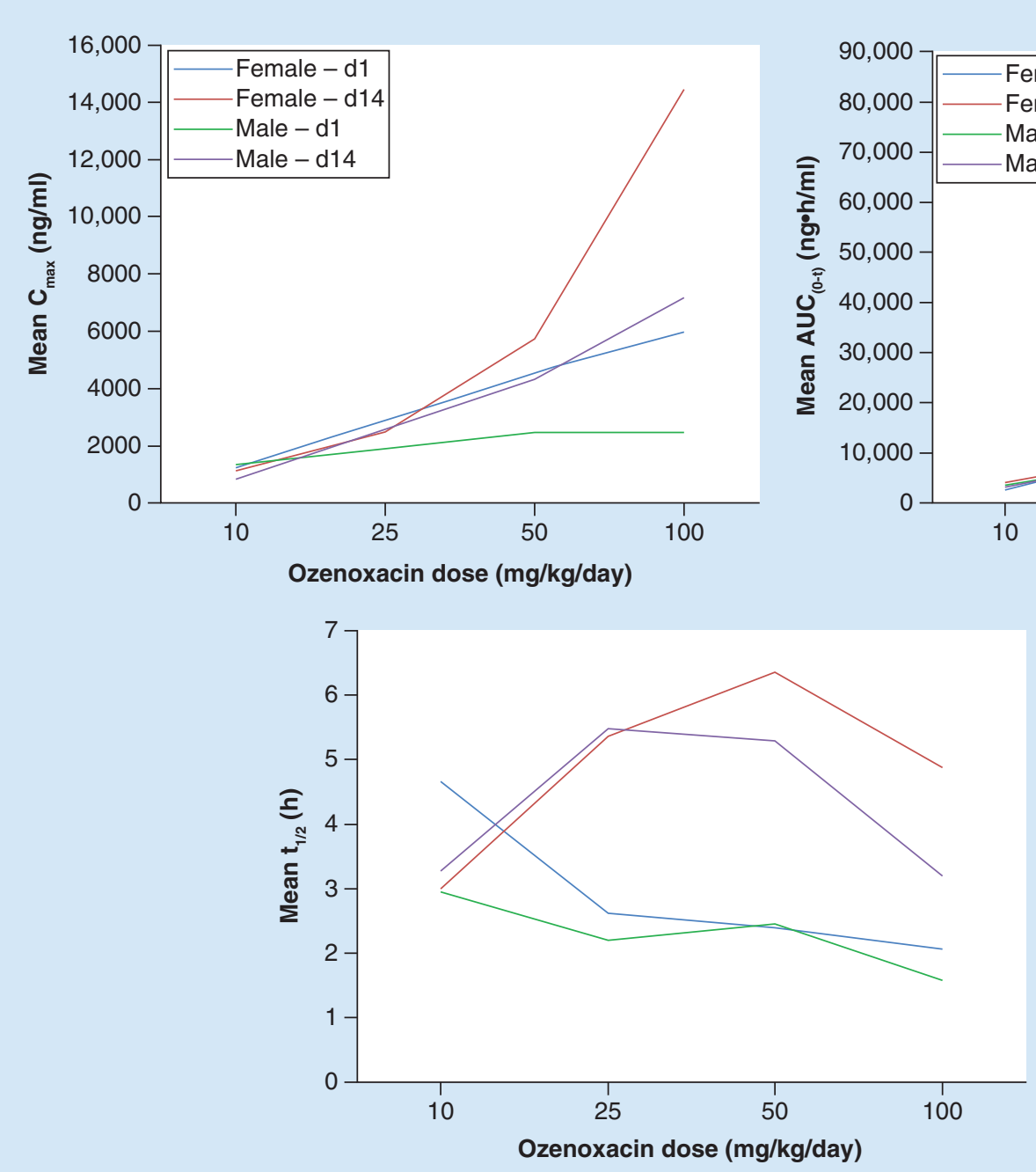
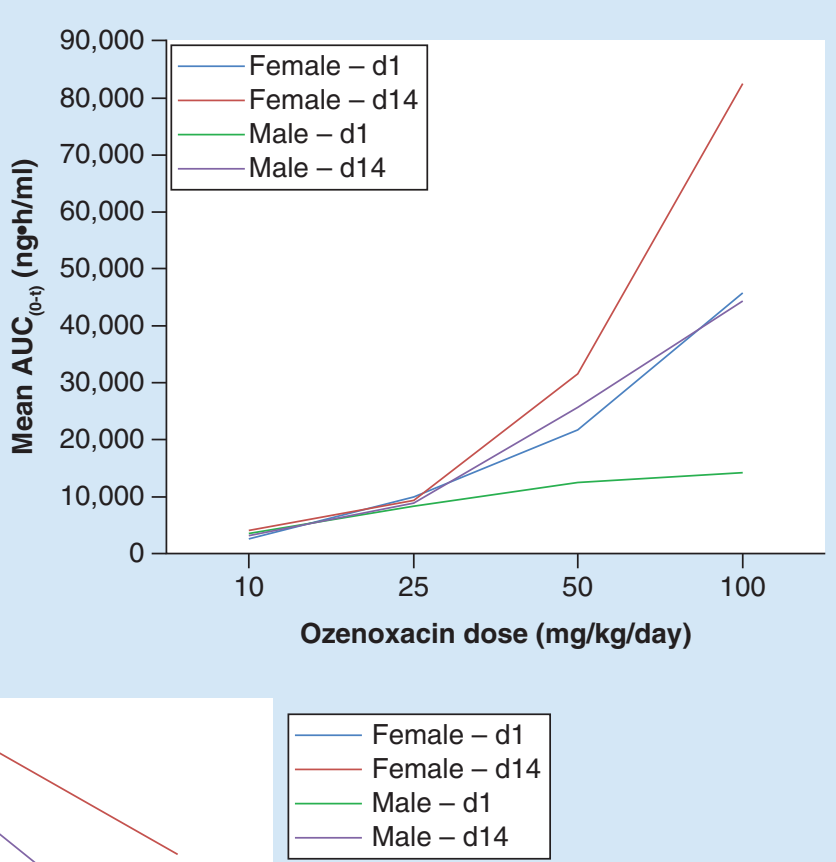

Figure 1. Toxicokinetic data for ozenoxacin in male and female dogs at days 1 and 14: mean $C_{\max }$ (upper left), mean AUC $\mathrm{C}_{0-\mathrm{t}}$ (upper right) and mean $t_{1 / 2}$ (lower).

AUC: Area under the curve; d: Day.

\section{Gross pathology}

There were no gross pathological changes related to oral ozenoxacin administration at the end of the treatment and recovery phases of the experiments. All macroscopic changes found in control and ozenoxacin-treated animals were considered to have no toxicological significance. There were no significant adverse effects on organ weights.

\section{Histopathology}

There was no evidence of quinolone-induced arthropathy following microscopic examination of bone or articular cartilage. All microscopic changes found in control and ozenoxacin-treated animals were considered incidental in origin and of no toxicological significance. Similarly, there were no ozenoxacin-related histopathological changes at the end of the treatment and recovery phases of the experiments in the selected organs examined.

\section{Bone length, mineral density \& mineral content}

There were no ozenoxacin-related effects on the length of the femur and tibia at the end of the 2-week treatment phase, and following the 2-week recovery phase. All variations noted were considered to be related to expected biological variation in the tested species. 


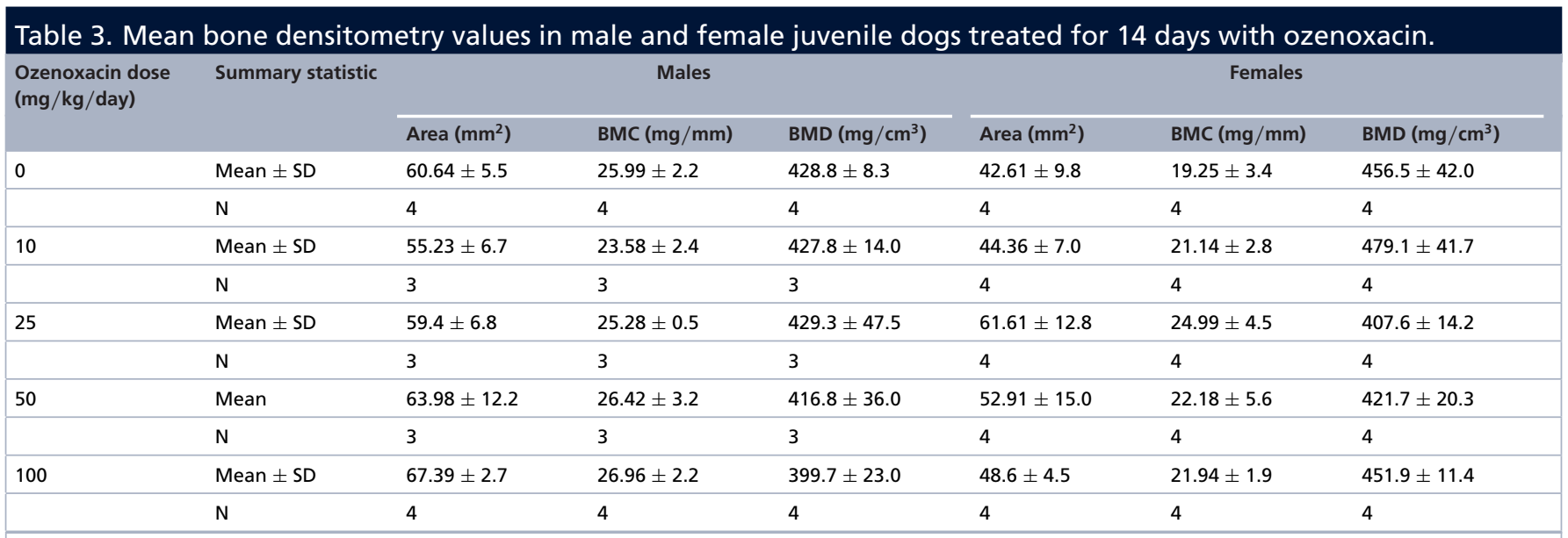

BMC: Bone mineral content; BMD: Bone mineral density; N: Number; SD: Standard deviation.

Ozenoxacin had no meaningful or consistent effects at the proximal radius metaphysis on bone mineral density (total, trabecular and cortical/subcortical), bone mineral content, and other bone geometry parameters, as assessed by peripheral quantitative computed tomography at the end of the treatment or recovery periods (Table 3 ).

\section{Discussion}

Fluoroquinolone antibacterial drugs present various safety concerns that are related to a range of substituents on the quinolone pharmacophore. Although these substituent changes have led to improved antibacterial activity, specific substitutions, for example, fluoride at the 6-position, are also associated with adverse events [14,15]. Ozenoxacin, which has no fluoride substituent at the six-position and lacks halogen substituents in other positions, is predicted to have an improved safety profile relative to other quinolone antibacterials.

Potential articular toxicity of ozenoxacin was assessed in juvenile rats and juvenile dogs, both of which are recognized models for evaluation of quinolone-induced arthropathy. Ozenoxacin did not induce arthropathy in either species after repeated oral administration during 5 days in rats and 14 days in dogs. In dogs, densitometry evaluations showed no toxicologically relevant effects of ozenoxacin on bone size or bone mass, and ex vivo bone measurement on femur and tibia showed no adverse effects on bone length.

Evidence of chondrotoxicity was found in three of ten juvenile rats treated with ofloxacin, with histopathology of the tibia-femur joint identifying chondromucinous degeneration accompanied by hyperplasic cartilage. These lesions are typical of those previously shown to be produced in juvenile rats by quinolones including ofloxacin [11,12] and ciprofloxacin $[13,16]$.

Data on articular toxicity in juvenile dogs for ozenoxacin obtained in the present study were compared with data for other quinolones reported in the scientific literature [9,17-18] and summarized in Table 4. The comparisons show that ozenoxacin was superior to other quinolones with regard to articular toxicity. Possible mechanisms for quinolone-induced chondrotoxicity include chelation of divalent cations $\left(\mathrm{Mg}^{2+}\right)$ or an effect on gene expression in articular cartilage [19-21]. However, the precise pathophysiology of fluoroquinolone-induced tendinopathy is uncertain and is probably multifactorial [15].

Orally administered ozenoxacin was well tolerated in juvenile rats. In this model, both ozenoxacin and ofloxacin produced a significant increase in AST but not ALT. In contrast, no effect of ozenoxacin on AST was observed in a previous study in juvenile rats in which a dose of $125 \mathrm{mg} / \mathrm{kg} /$ day was administered over a longer period of time (28 days). The $125 \mathrm{mg} / \mathrm{kg} /$ day dose was considered to be the NOAEL in adult rats [22].

In juvenile dogs, orally administered ozenoxacin up to $100 \mathrm{mg} / \mathrm{kg} /$ day for 2 weeks produced tremors and decreased activity due to a probable effect on the CNS, and emesis due to possible gastrointestinal irritation. These effects, which were reversible and not considered to be toxicologically relevant, were observed only at higher doses $(\geq 50 \mathrm{mg} / \mathrm{kg} /$ day $)$ and were clearly related to high systemic exposure of ozenoxacin; they were attributed to secondary effects of the quinolone. The CNS effects in males at $100 \mathrm{mg} / \mathrm{kg} /$ day and in females at 50 and $100 \mathrm{mg} / \mathrm{kg} /$ day were dose-related and were not observed during the recovery period. These CNS effects are related to high plasma exposure levels of ozenoxacin obtained in juvenile animals after oral administration for 14 consecutive 


\begin{tabular}{|c|c|c|c|c|c|}
\hline Treatment groups [Ref.] & Dose $(\mathrm{mg} / \mathrm{kg})$ & $\begin{array}{l}\text { Juvenile dogs (aged } \\
3-4 \text { months) }\end{array}$ & Mean $C_{\max }(\mu \mathbf{g} / \mathrm{ml})$ & Mean $A \cup C_{(0-t)}(\mu g \bullet h / m l)$ & $\begin{array}{l}\text { Articular lesions } \\
\text { reported: yes } / \text { no } \\
\text { (frequency) }\end{array}$ \\
\hline $\begin{array}{l}\text { Norfloxacin (oral) } \\
\text { (TK at } 6 \text { days } \\
\text { treatment) [9] }\end{array}$ & 50 & $\begin{array}{l}\text { Male } \\
\text { Female }\end{array}$ & $\begin{array}{l}2.04 \pm 1.04 \\
1.72 \pm 1.10\end{array}$ & $\begin{array}{l}11.9 \pm 3.7 \\
13.1 \pm 8.8\end{array}$ & $\begin{array}{l}\text { Yes }(2 / 3 \text { animals in } \\
\text { humerus, } 1 / 3 \text { animals in } \\
\text { femur) } \\
\text { Yes }(1 / 3 \text { animals in } \\
\text { humerus, } 2 / 3 \text { animals in } \\
\text { femur) }\end{array}$ \\
\hline $\begin{array}{l}\text { Grepafloxacin (iv.) } \\
\text { (TK after } 30 \mathrm{~min} \\
\text { infusion) [18] }\end{array}$ & 100 & Male & $12.79 \pm 3.19$ & - & Yes ( $1 / 3$ animals in femur) \\
\hline $\begin{array}{l}\text { Ozenoxacin (oral; current } \\
\text { study) } \\
\text { (TK at } 14 \text { days treatment) }\end{array}$ & 100 & $\begin{array}{l}\text { Male } \\
\text { Female }\end{array}$ & $\begin{array}{l}7.1 \\
14.5\end{array}$ & $\begin{array}{l}44.4 \\
82.5\end{array}$ & $\begin{array}{l}\text { No }(0 / 6 \text { animals; no lesions } \\
\text { observed in humerus, femur } \\
\text { and tibia) }\end{array}$ \\
\hline
\end{tabular}

days. Effects were seen mainly in females, where there was greater overall exposure at 50 and $100 \mathrm{mg} / \mathrm{kg} /$ day doses (up to 3.25-fold higher compared with males).

The non-dose-dependent changes in albumin and globulin concentrations at ozenoxacin doses $\geq 10 \mathrm{mg} / \mathrm{kg} / \mathrm{day}$ were generally within historical ranges for the age of the dogs and were not considered to be adverse or toxicologically relevant, despite a lack of reversibility. The reason for the non-dose-dependent decrease in total and differential WBC counts with ozenoxacin at doses $\geq 10 \mathrm{mg} / \mathrm{kg} /$ day is unclear, although it may involve the pharmacodynamic properties of this quinolone. Furthermore, it is important to consider that in this study of juvenile dogs there were no adverse effects on organ weights or any macroscopic or microscopic changes in the five selected organs examined.

There was considerable variability in plasma concentrations of ozenoxacin in the dog model. The greater overall exposure of ozenoxacin at doses of 50 and $100 \mathrm{mg} / \mathrm{kg} /$ day in female dogs is consistent with the greater frequency of clinical signs observed in females. Overall, analysis of $\mathrm{C}_{\max }$ and mean $A \mathrm{UC}_{(0-\mathrm{t})}$ data on day 1 and day 14 showed that plasma exposure was related to dose. On day 14 of treatment at the NOAEL of ozenoxacin in this model $(100 \mathrm{mg} / \mathrm{kg} /$ day $)$, mean $\mathrm{C}_{\max }$ and AUC $(0-\mathrm{t})$ values in male dogs $(7125 \mathrm{ng} / \mathrm{ml}$ and $44,441 \mathrm{ng} \bullet \mathrm{h} / \mathrm{ml}$, respectively) were approximately half those in female dogs $(14,468 \mathrm{ng} / \mathrm{ml}$ and $82,475 \mathrm{ng} \bullet \mathrm{h} / \mathrm{ml}$, respectively).

In clinical practice, ozenoxacin $1 \%$ cream is not intended for systemic administration, being applied topically at a maximum dose of $0.5 \mathrm{~g}$ twice a day for 5 days and not surpassing a body surface area of $100 \mathrm{~cm}^{2}$. After accidental oral intake of one dose, the amount that could be swallowed is $0.031-0.93 \mathrm{mg} / \mathrm{kg}$, which is far lower than the HED derived from doses administered to rats $(300 \mathrm{mg} / \mathrm{kg})$ or dogs $(100 \mathrm{mg} / \mathrm{kg})$. Following administration of ozenoxacin $1 \%$ cream to patients with impetigo, there was no evidence of systemic absorption [23], with high concentrations found in the stratum corneum following topical administration to healthy volunteers [24].

\section{Conclusion}

Following repeated oral administration to juvenile rats and dogs, ozenoxacin was generally well tolerated with no evidence of quinolone-induced arthropathy in these recognized animal models for evaluation of articular toxicity of quinolones. Furthermore, ozenoxacin did not induce toxicologically relevant findings in five organ systems examined (brain, thymus, liver, lung and kidney) after adequate systemic exposure in juvenile dogs. The HED derived from the NOAEL $(100 \mathrm{mg} / \mathrm{kg} /$ day $)$ in juvenile dogs is between 41 and 323 times higher than the expected clinical dose in humans after topical use of ozenoxacin. This confers a high safety margin for the approved indication of ozenoxacin in adults and children. 


\section{Future perspective}

Since their introduction more than 40 years ago, new quinolone compounds continue to be developed, with improved antibacterial activity and safety profiles. For example, the development of the nonfluorinated quinolone, ozenoxacin, avoids the adverse effects associated with fluoroquinolones, which contain a fluoride atom at the six-position of the quinolone molecule. Continued development of quinolone antibacterials may further improve the range of antibacterial activity and safety profiles. In common with other antimicrobials, the development of resistance to quinolone antibacterial compounds is an issue which needs to be addressed in the immediate future.

\section{Summary points}

- Ozenoxacin is a nonfluorinated quinolone antibacterial approved for topical treatment of impetigo as a $1 \%$ cream formulation. Because quinolones have known chondrotoxic effects in juvenile animals, the potential toxicity of ozenoxacin was assessed in preclinical studies.

- Ozenoxacin or ofloxacin (300 mg/kg/day for 5 days, for each compound) was administered orally to juvenile rats, and oral ozenoxacin (from 10 to $100 \mathrm{mg} / \mathrm{kg} /$ day for 14 days) was administered to juvenile dogs.

- In juvenile rats, ozenoxacin showed no chondrotoxicity, whereas ofloxacin produced typical quinolone-induced lesions in articular cartilage in three of ten rats.

- After administration of oral ozenoxacin to juvenile dogs there was no microscopic evidence of quinolone-induced arthropathy in examined bone/articular cartilage; or any effects on bone size or bone mass; and there were no relevant toxicological macroscopic or histopathological findings in selected target organs examined (brain, thymus, liver, lungs and kidneys).

- In conclusion, ozenoxacin was generally well tolerated in juvenile rats and dogs, with no evidence of quinolone-induced arthropathy or induction of toxicologically relevant findings in other organ systems after adequate systemic exposure.

- The human equivalent dose derived from the no observed adverse effect level $(100 \mathrm{mg} / \mathrm{kg} /$ day $)$ in juvenile dogs is between 41 and 323 times higher than the expected clinical dose in humans after topical use of ozenoxacin. This confers a high safety margin for the approved indication of ozenoxacin in adults and children.

\section{Financial \& competing interests disclosure}

The studies were supported by Ferrer Internacional, Barcelona, Spain. MS Awori and SY Smith were employees of Charles River Laboratories at the time the studies were performed. C Tarragó and T Blazquez were employees of Ferrer Internacional at the time the studies were performed. JI González Borroto and I Zsolt are current employees of Ferrer Internacional. The authors have no other relevant affiliations or financial involvements with any organization or entity with a financial interest in or financial conflict with the subject matter or materials discussed in the manuscript apart from those disclosed.

Writing assistance was provided by Content Ed Net (Madrid, Spain) with funding provided by Ferrer International SA (Barcelona, Spain).

\section{Ethical conduct of research}

This study was completed in accordance with Organisation for Economic Co-operation and Development guidelines [25].

\section{References}

Papers of special note have been highlighted as: $\bullet$ of interest; $\bullet \bullet$ of considerable interest

1. Van Bambeke F, Michot JM, Van Eldere J et al. Quinolones in 2005: an update. Clin. Microbiol. Infect. 11, 256-280 (2005).

2. Yamakawa T, Mitsuyama J, Hayashi K. In vitro and in vivo antibacterial activity of T-3912, a novel non-fluorinated topical quinolone. J. Antimicrob. Chemother. 49, 455-465 (2002).

-• Preclinical study of the efficacy of oxenoxacin showing its bactericidal activity.

3. López Y, Tato M, Espinal P et al. In vitro activity of ozenoxacin against quinolone-susceptible and quinolone-resistant Gram-positive bacteria. Antimicrob. Agents Chemother. 57, 6389-6392 (2013).

-• In vitro antibacterial activity of ozenoxacin against microorganisms isolated from skin and soft tissue infections.

4. Albareda N, Zeichner J, Rosenberg $\mathrm{N}$ et al. A randomized vehicle-controlled trial to assess the efficacy, safety, and tolerability of ozenoxacin 1\% cream in 412 patients 2 months and older with impetigo. SKIN The Journal of Cutaneous Medicine 1, s103 (2017).

- Phase III clinical trial showing the efficacy and safety of oxenoxacin $1 \%$ cream in patients with impetigo.

5. Gropper S, Albareda N, Chelius K et al. Ozenoxacin 1\% cream in the treatment of impetigo: a multicenter, randomized, placebo- and retapamulin-controlled clinical trial. Future Microbiol. 9(9), 1013-1023 (2014). 
-. Phase III clinical showing the efficacy and safety of ozenoxacin $1 \%$ cream for the treatment of impetigo.

6. Stahlmann R. Safety profile of the quinolones. J. Antimicrob. Chemother. 26(Suppl. D), 31-44 (1990).

7. Hildebrand H, Kempka G, Schlüter G et al. Chondrotoxicity of quinolones in vivo and in vitro. Arch. Toxicol. 67, 411-415 (1993).

8. Stahlmann R, Zippel U, Förster C et al. Chondrotoxicity and toxicokinetics of sparfloxacin in juvenile rats. Antimicrob. Agents Chemother. 42, 1470-1475 (1998).

9. Nagai A, Miyazaki M, Morita T et al. Comparative articular toxicity of garenoxacin, a novel quinolone antimicrobial agent, in juvenile beagle dogs. J. Toxicol. Sci. 27, 219-228 (2002).

10. Yabe K, Satoh H, Ishii Y et al. Early pathophysiologic feature of arthropathy in juvenile dogs induced by ofloxacin, a quinolone antimicrobial agent. Vet. Pathol. 41, 673-681 (2004).

11. Stahlmann R, Merker HJ, Hinz $\mathrm{N}$ et al. Ofloxacin in juvenile non-human primates and rats. Arthropathia and drug plasma concentrations. Arch. Toxicol. 64, 193-204 (1990).

12. Çavuşoğlu I, Kahveci Z, Noyan S et al. Quinolone arthropathy induced by ofloxacin in juvenile rats: a light microscopic study. Turk. J. Med. Sci. 30, 441-447 (2000).

13. Li P, Cheng NN, Chen BY et al. In vivo and in vitro chondrotoxicity of ciprofloxacin in juvenile rats. Acta Pharmacol. Sin. 25, 1262-1266 (2004).

14. Mandell L, Tillotson G. Safety of fluoroquinolones: an update. Can. J. Infect. Dis. 13, 54-61 (2002).

15. Thompson AM. Ocular toxicity of fluoroquinolones. Clin. Experiment. Ophthalmol. 35, 566-577 (2007).

16. von Keutz E, Rühl-Fehlert C, Drommer W et al. Effects of ciprofloxacin on joint cartilage in immature dogs immediately after dosing and after a 5-month treatment-free period. Arch Toxicol. 78, 418-424 (2004).

17. Yabe K, Murakami Y, Nishida S et al. A non-arthropathic dose and its disposition following repeated oral administration of ofloxacin a new quinolone antimicrobial agent to juvenile dogs. J. Vet. Med. Sci. 63, 867-872 (2001).

18. Takizawa T, Hashimoto K, Minami T, Yamashita S, Owen K. The comparative arthropathy of fluoroquinolones in dogs. Hum. Exp. Tox. 18, 392-399 (1999).

19. Stahlmann R, Förster C, Shakibaei M et al. Magnesium deficiency induces joint cartilage lesions in juvenile rats which are identical to quinolone-induced arthropathy. Antimicrob. Agents Chemother. 39, 2013-2018 (1995).

20. Goto K, Yabe K, Suzuki T et al. Gene expression profiles in the articular cartilage of juvenile rats receiving the quinolone antibacterial agent ofloxacin. Toxicology 249, 204-213 (2008).

21. Goto K, Yabe K, Suzuki T et al. Chondrotoxicity and toxicokinetics of novel quinolone antibacterial agents DC-159a and DX-619 in juvenile rats. Toxicology 276, 122-127 (2010).

22. Ferrer Group. Ozenoxacin: 28-day repeated dose oral toxicity in rats with 14-day recovery period. Report: RR-030050-01 (2004).

23. Gropper S, Cepero AL, Santos B et al. Systemic bioavailability and safety of twice-daily topical ozenoxacin $1 \%$ cream in adults and children with impetigo. Future Microbiol. 9(Suppl. 8), S33-S40 (2014).

24. Gropper S, Albareda N, Santos B et al. Skin tissue exposure of once- versus twice-daily topical ozenoxacin $2 \%$ cream: a Phase I study in healthy volunteers. Future Microbiol. 9(Suppl. 8), S17-S22 (2014).

25. OECD. Guidance document on the recognition, assessment and use of clinical signs as human endpoints for experimental animals used in safety evaluation. (2002). www.oecd-ilibrary.org/environment/guidance-document-on-the-recognition-assessment-and-use-of-clini cal-signs-as-human-endpoints-for-experimental-animals-used-in-safety-evaluation_9789264078376-en 